Article

\title{
All-Solid-State Calcium Sensors Modified with Polypyrrol (PPY) and Graphene Oxide (GO) as Solid-Contact Ion-to-Electron Transducers
}

\author{
Hisham S. M. Abd-Rabboh ${ }^{1,2} \mathbb{D}$, Ayman H. Kamel ${ }^{2} \mathbb{D}$ and Abd El-Galil E. Amr 3,4,*(D) \\ 1 Chemistry Department, Faculty of Science, King Khalid University, Abha 61413, Saudi Arabia; \\ habdrabboh@kku.edu.sa \\ 2 Department of Chemistry, Faculty of Science, Ain Shams University, Cairo 11566, Egypt; \\ ahkamel76@sci.asu.edu.eg \\ 3 Pharmaceutical Chemistry Department, Drug Exploration \& Development Chair (DEDC), \\ College of Pharmacy, King Saud University, Riyadh 11451, Saudi Arabia \\ 4 Applied Organic Chemistry Department, National Research Center, Dokki, Giza 12622, Egypt \\ * Correspondence: aamr@ksu.edu.sa; Tel.: +966-565-148-750
}

Received: 17 August 2020; Accepted: 26 September 2020; Published: 30 September 2020

\begin{abstract}
Reliable, cost-effective, and robust screen-printed sensors were constructed and presented for $\mathrm{Ca}^{2+}$ ions determination. The sensors were based on the use of bilirubin (1,3,6,7-tetramethyl-4,5dicarboxyethy-2,8-divinyl-(b-13)-dihydrobilenone) as a recognition sensory material in plasticized poly (vinyl chloride) (PVC) membranes. Polypyrrol (PPY) and graphene oxide (GO) were used as ion-to-electron transducers, where the effects of anionic excluder, $\mathrm{pH}$, and selectivity were investigated. In a $50 \mathrm{mM}$ tris buffer solution of $\mathrm{pH} 5$, the electrodes offered a potential response for $\mathrm{Ca}^{2+}$ ions with a near-Nernstian slopes of $38.1 \pm 0.4\left(\mathrm{r}^{2}=0.996\right)$ and $31.1 \pm 0.6\left(\mathrm{r}^{2}=0.999\right)$, detection limits $3.8 \times 10^{-6}$ $(0.152 \mu \mathrm{g} / \mathrm{mL})$ and $2.3 \times 10^{-7} \mathrm{M}(8.0 \mathrm{ng} / \mathrm{mL})$, and linear concentration ranges of $7.0 \times 10^{-6}-1.0 \times 10^{-2}$ $(400-0.28 \mu \mathrm{g} / \mathrm{mL})$ and $7.0 \times 10^{-7}-1.0 \times 10^{-2} \mathrm{M}(400-0.028 \mu \mathrm{g} / \mathrm{mL})$ for sensors based on PPY and GO, respectively. Both sensors revealed stable potentiometric responses with excellent reproducibility and enhanced selectivity over a number of most common metal ions, such as $\mathrm{Na}^{+}, \mathrm{K}^{+}, \mathrm{Li}^{+}, \mathrm{NH}_{4}{ }^{+}$, $\mathrm{Fe}^{2+}, \mathrm{Mg}^{2+}$, and $\mathrm{Ba}^{2+}$. Impedance spectroscopy and chronopotentiometric techniques were used for evaluating the potential drift and the interfacial sensor capacitance. The proposed sensors offered the advantages of simple design, ability of miniaturization, good potential stability, and cost-effectiveness. The developed electrodes were applied successfully to $\mathrm{Ca}^{2+}$ ion assessment in different pharmaceutical products, baby-food formulations, and human blood samples. The results obtained were compared with data obtained by atomic absorption spectrometry (AAS).
\end{abstract}

Keywords: potentiometric sensors; screen-printed electrodes; polypyrrol (PPY); graphene oxide (GO); chronopotentiometry; impedance spectroscopy

\section{Introduction}

Calcium is an important element that plays an essential physiological role in the human body, along with $\mathrm{Na}^{+}, \mathrm{K}^{+}, \mathrm{Cl}^{-}$, and $\mathrm{Mg}^{2+}$. It is mandatory for bone formation that plays the role of support and protection of the human body. Calcium is necessary for cell secretion, signal transmission, chemical, and electrical stimulation for neuromuscular transmission, as well as blood clotting [1]. Therefore, the calcium assessment in human blood is essential in the medical field within intensive care units [2], in open-heart surgeries and cardiovascular treatments [3], and in organ transplants [4].

Calcium sensors based on potentiometric transduction have been developed several decades ago and were pioneered by Ross [5]. The measurement of ionized calcium in environmental, industrial, 
and clinical blood samples require reliable, sensitive, rapid, and cost-effective methods [6,7]. Of all the electrochemical techniques, potentiometry is probably the most preferred technique that fulfills all of these advantages. Potentiometric sensors "ion-selective electrodes" (ISEs), in a short time frame, can provide sensitive and reliable measurements for clinically critical analyses of small sample sizes [8-10]. In addition, the measuring devices for potentiometric sensors have the advantages of small size, simplicity of use, and provide fast and reliable responses.

There is an increasing importance to realize compact sensing devices. Therefore, the design and manufacture of solid-state reference electrodes that are easy to miniaturize and the cost-effectiveness of their mass production are becoming increasingly important to achieve this purpose. Recently, there has been an increasing and accelerating demand for wearable sensors and point-of-care tests that provide real-time information on health standards, and many of these systems are operated electrochemically. The all-solid-state ISEs, especially, are attractive for wide range of practical applications because they are liquid junction free, pressure resistant, easy to pack and seal, and allow for the miniaturization for portable devices [11-14]. To fabricate these types of ISEs, it requires careful design of a solid electronic conductor and solid-contact material, due to their mixed ionic and electronic conductivity through solution-casting [15]. Different solid electronic conductors were investigated in the fabrication of solid-contact ISEs, such as gold [16,17], platinum [18,19], silicon [20], graphite/epoxy [21], and glassy carbon [22]. These materials are suffering from either the high cost or complication in the fabrication process. All solid-planar electrodes are based on electrodes made of an electronic solid-conductor coated by the ion-sensing membrane (ISM) and a conducting solid-contact layer is inserted [23]. The processing of thick films is effective for manufacturing compact and easily reproducible structural sensors at a modest cost [24] and leads to the feasibility of mass production of portable disposable sensors for point of care testing [25].

Bilirubin consists of an open chain tetrapyrrole. It is formed by the oxidative cleavage of porphyrin in heme, which affords biliverdin. Its structure has four methyl groups, two propionic acid groups, and two vinyl radicals. Bilirubin has a great affinity towards $\mathrm{Ca}^{2+}$ forming $\mathrm{Ca}$ (II)-bilirubinate complex, in which four nitrogen atoms of bilirubin surround a $\mathrm{Ca}(\mathrm{II})$ ions in a quasi-square planer arrangement $[26,27]$.

In this work, we report new screen-printed calcium sensors based on bilirubin as a recognition sensory material and tetrakis-(p-chlorophenyl) borate as a lipophilic anion. The plasticized PVC membrane was coated on either polypyrrol (PPY) or graphene oxide (GO) as solid contact transducers. Performance characteristics of the proposed sensors, including sensitivity, selectivity, pH effect, and potential stability were studied. The capacitative character of solid contact transducers was evaluated using electrochemical impedance spectroscopy (EIS) and chronopotentiometric techniques. The sensors were successfully applied for monitoring $\mathrm{Ca}^{2+}$ ions in some pharmaceutical formulations, baby-food products, and human serum plasma.

\section{Experimental}

\subsection{Apparatus}

Screen-printed carbon electrodes (SPCEs) modified with a monolayer of either polypyrrol (PPY) (Ref. 110PPYR) or graphene oxide (GO) (Ref. 110GPHOX) were purchased from DropSens (LLanera, Asturias, Spain). The platforms were of ceramic substrate $(\mathrm{L} 34 \times \mathrm{W} 10 \times \mathrm{H} 0.5 \mathrm{~mm})$ and silver as an electrical contact. The electrochemical cell consists of either GO/carbon or PPY/carbon (4 mm) acting as a working electrode and $\mathrm{Ag} / \mathrm{AgCl}$ as a reference electrode. All potentiometric measurements were carried out at ambient temperature using a $\mathrm{pH} / \mathrm{mV}$ ion meter (PXSJ-216 INESA Scientific Instrument Co., Ltd, Shangahi, China). Electrochemical impedance spectroscopy (EIS) and chronopotentiometry data were obtained using a potentiostat/galvanostat (Metrohom, Autolab 204, Herisau, Switzerland). 


\subsection{Materials and Reagents}

Bilirubin, high molecular weight poly (vinyl chloride) (PVC), (o-nitrophenyloctyl ether (o-NPOE), and tetrahydrofuran (THF) were obtained from Sigma (St. Louis, MO, USA). Potassium tetrakis (4-chlorophenyl) borate (KTClPB) was purchased from Fluka AG (Buchs, Switzerland). All other chemicals were of analytical grade quality.

A stock $10^{-1} \mathrm{M}$ solution of $\mathrm{Ca}^{2+}$ was prepared by dissolving anhydrous $\mathrm{CaCl}_{2}$ salt in de-ionized water and then standardized via its titration with EDTA solution.

\subsection{Sensors' Construction}

Plasticized poly (vinyl chloride) (PVC) membrane sensors were fabricated using $o$-NPOE plasticizer in the presence of KTCIPB as an anionic excluder. The composition of the membrane consisted of $3.0 \mathrm{wt} \%$ bilirubin ionophore ( $3.0 \mathrm{mg}), 1.5 \mathrm{wt} \%$ KTClPB $(1.5 \mathrm{mg}), 31.5 \mathrm{wt} \%$ PVC (31.5 mg), and $63.5 \mathrm{wt} \%$ $o$-NPOE $(63.5 \mathrm{mg})$. All were dissolved in $2 \mathrm{~mL}$ THF solvent. Subsequently, $100 \mu \mathrm{L}$ of the membrane cocktail was drop-casted over the transducer layer (PPY for sensor I or GO for sensor II) coating the carbon conductor in the screen-printed electrode. The sensors were stored in dry place for 4 hours, then soaked in $10^{-4} \mathrm{M} \mathrm{Ca}^{2+}$ solution for one day, followed by another two days in a $10^{-7} \mathrm{M} \mathrm{Ca}^{2+}$ ion solution.

\subsection{Electrochemical Impedance Spectroscopy and Chronopotentiometry}

Electrochemical impedance spectroscopy (EIS) and chronopotentiometry measurements were carried out in $10^{-4} \mathrm{M} \mathrm{CaCl}_{2}$ solution using a conventional three-electrode system, where the studied sensor was connected as the working electrode. The reference electrode of the system was $\mathrm{Ag} / \mathrm{AgCl}$ $(3 \mathrm{M} \mathrm{KCl})$, and the auxiliary electrode was made from a platinum wire. The impedance spectra were recorded at open circuit potential with an amplitude $100 \mathrm{mV}$ and in the frequency range $0.1 \mathrm{~Hz}-100 \mathrm{kHz}$. The reversed-current chronopotentiometry was carried out after applying a constant current of a value $\pm 1 \mathrm{nA}$ for $120 \mathrm{~s}$.

\subsection{Calcium Assessment in Real Samples}

The proposed sensors were used for calcium determination in some baby-food products, human serum, and some pharmaceutical formulations. For baby-food samples, a $1.0 \mathrm{~g}$ sample was mixed with $10 \mathrm{~mL}$ of $(1: 1) \mathrm{HNO}_{3}$ in a silica crucible, and the mixture was heated till dryness. To the obtained residue, a $5 \mathrm{~mL}$ volume of $0.1 \mathrm{M} \mathrm{HCl}$ was added and the mixture was then heated for further $1 \mathrm{~h}$. The solution was filtered and collected in a $50 \mathrm{~mL}$ volumetric flask, then completed to the mark with $50 \mathrm{mM}$ tris buffer $(\mathrm{pH}=5)$. This solution was stored in a brown bottle and analyzed using the proposed sensors, in comparison with the atomic absorption spectroscopy (AAS) reference method.

Calcium is assessed by oral dosage of the pharmaceutical products labeled commercially as Calcimate (500 mg/tablet) (ADWIC, Oubour, Qalyubia, Egypt) and Vitacid calcium ( $800 \mathrm{mg} / \mathrm{tablet}$ ) (CID, Talbeyah Al Qebleyah, El Talbia, Giza Governorate, Egypt). Three tablets of each formulation containing calcium were grinded into a homogeneous fine powder using an agate mortar. A definite amount of the mixed finely powdered 3 tablets, equivalent to one tablet, was accurately transferred into a $50 \mathrm{~mL}$ beaker and $5 \mathrm{~mL}$ of (1:1) $\mathrm{HCl}$ added. The reaction mixture was then sonicated for $10 \mathrm{~min}$ and heated for a further $1 \mathrm{~h}$ at $80^{\circ} \mathrm{C}$. The solution was transferred after cooling into a $100 \mathrm{~mL}$ calibrated flask and completed to the mark with $50 \mathrm{mM}$ tris buffer $(\mathrm{pH}=5)$. Potential measurements of sample solutions were recorded and $\mathrm{Ca}^{2+}$ ion concentrations were calculated using the standard calibration curve method.

For calcium determination in human serum, blood samples were acquired from healthy humans with informed consent and then stored refrigerated for $8 \mathrm{hrs}$ before extracting its serum. Serum was extracted after centrifugation at $12,000 \mathrm{rpm}$ for $20 \mathrm{~min}$. A $2.0 \mathrm{~mL}$ sample of clear blood serum is transferred into a $250 \mathrm{~mL}$ calibrated flask. The sample is diluted to $50 \mathrm{~mL}$ with de-ionized water. 
Then, $9 \mathrm{~mL}$ of $50 \mathrm{mM}$ tris buffer solution of $\mathrm{pH} 5$ was added. The mixture was mixed and used for calcium measurements. The sensors were immersed in the sample solution and the potential values were plotted versus $\log \left(\mathrm{Ca}^{2+}\right)$ concentration to construct the calibration plot. The study protocol was approved by the National Research Centre Medical Research Ethics Committee (HU/IACUC20187).

\section{Results and Discussion}

\subsection{Performance Characteristics of the Proposed Sensors}

The performance characteristics of the proposed sensors, in terms of working concentration range, detection limit, slope sensitivity and response time were evaluated and determined. All data obtained from the potentiometric measurements were summarized in Table 1. As shown in the constructed calibration curve (Figure 1), the developed C/PPY/Ca ${ }^{2+}$-ISEs and C/GO/Ca ${ }^{2+}$-ISEs revealed linear ranges of $7.0 \times 10^{-6}-1.0 \times 10^{-2}$ and $7.0 \times 10^{-7}-1.0 \times 10^{-2} \mathrm{M}$ with Nernstian slopes of $38.1 \pm 0.4$ $\left(\mathrm{r}^{2}=0.996\right)$ and $31.1 \pm 0.6\left(\mathrm{r}^{2}=0.999\right) \mathrm{mV} /$ decade, respectively. The detection limits for the two sensors were found to be $3.8 \times 10^{-6}$ and $2.3 \times 10^{-7} \mathrm{M}$, respectively. The un-modified C/Ca ${ }^{2+}$-ISE revealed a near-Nernstian slope of $34.7 \pm 0.3 \mathrm{mV} /$ decade over the linear range of $1.0 \times 10^{-5}-1.0 \times 10^{-2} \mathrm{M}$ and a detection limit of $8.0 \times 10^{-6} \mathrm{M}$. The chemical structure of both bilirubin and calcium bilirubinate complex, in addition to a scheme for electrode response mechanism, is presented in Figure 2.

Table 1. Potentiometric characteristics of SPC/Ca ${ }^{2+}$-ISEs in $50 \mathrm{mM}$, tris buffer solution $(\mathrm{pH}=5)$.

\begin{tabular}{cccc}
\hline Parameter & C/PPY/Ca & \\
\hline Slope $(\mathrm{ISEs}$ & $\mathbf{C} / \mathrm{GO} / \mathbf{C a}^{2+}$-ISEs & C/Ca $^{2+}$-ISEs \\
Correlation coefficient $\left(\mathrm{r}^{2}\right)$ & $38.1 \pm 0.4$ & $31.1 \pm 0.6$ & $34.7 \pm 0.3$ \\
Linear range (M) & 0.996 & 0.999 & 0.995 \\
Detection limit (M) & $7.0 \times 10^{-6}-1.0 \times 10^{-2}$ & $7.0 \times 10^{-7}-1.0 \times 10^{-2}$ & $1.0 \times 10^{-5}-1.0 \times 10^{-2}$ \\
Working acidity range (pH) & $3.8 \times 10^{-6}$ & $2.3 \times 10^{-7}$ & $8.0 \times 10^{-6}$ \\
Response time (s) & $4.0-7.4$ & $3.5-8.4$ & $3.5-8.4$ \\
Accuracy (\%) & $<5$ & $<5$ & $<5$ \\
Precision (\%) & 99.1 & 99.4 & 98.8 \\
Trueness (\%) & 1.3 & 0.7 & 1.1 \\
Bias (\%) & 99.2 & 99.3 & 98.7 \\
Within-day repeatability (\%) & 0.6 & 0.4 & 0.9 \\
Between-days variations (\%) & 0.8 & 0.5 & 1.1 \\
\hline
\end{tabular}

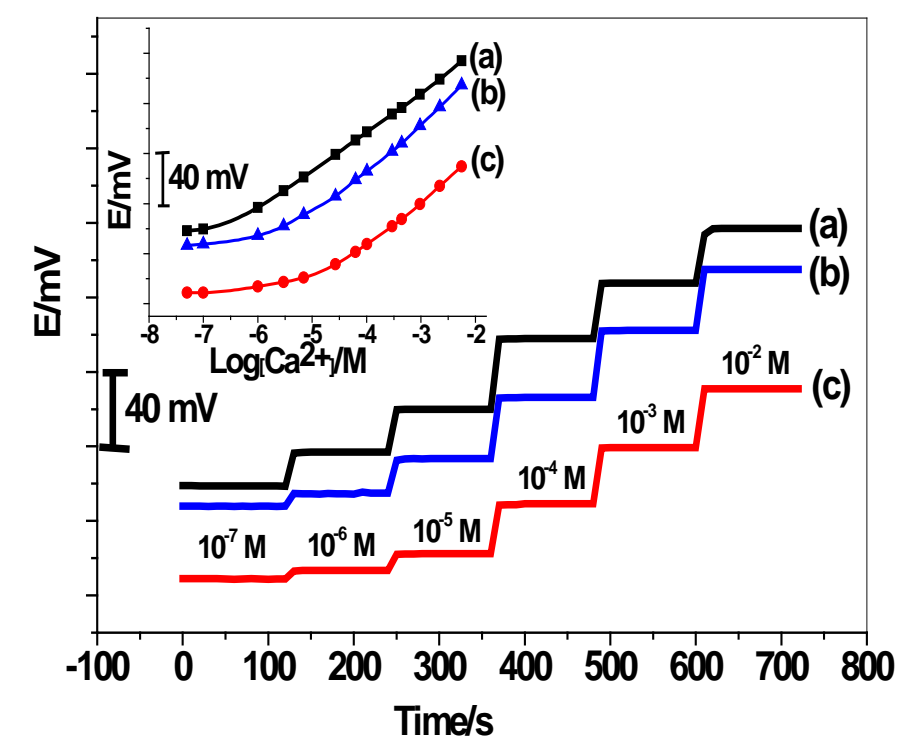

Figure 1. Calibration plots of the proposed calcium-solid contact selective electrodes: (a) C/GO/Ca ${ }^{2+}$-ISEs; (b) C/PPY/Ca ${ }^{2+}$-ISEs; and (c) $\mathrm{C} / \mathrm{Ca}^{2+}$-ISEs. 

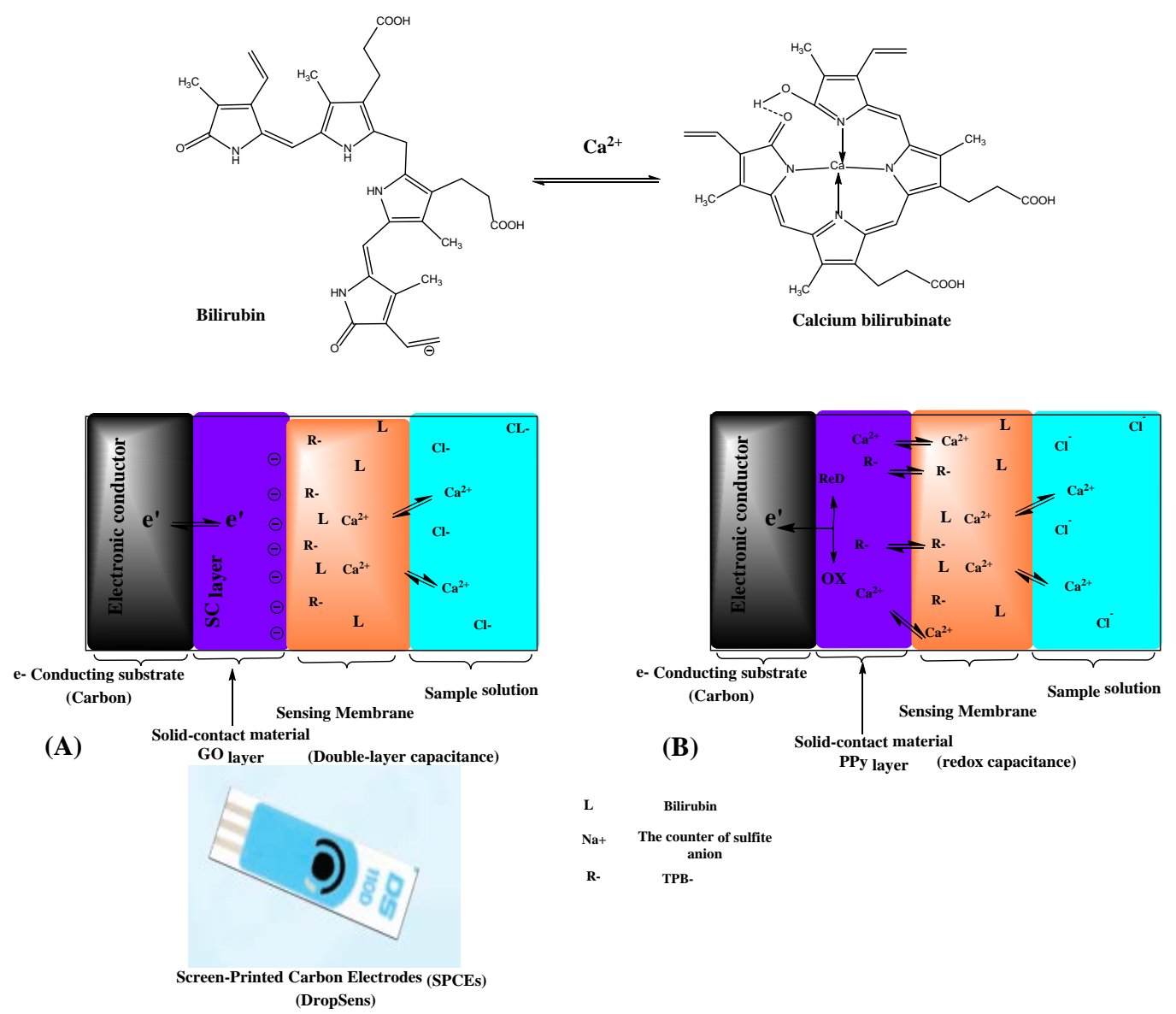

R- $\quad$ TPB-

Figure 2. Structure of both bilirubin and calcium bilirubinate complex. (A) an SC/ISE with GO layer (double-layer capacitance layer) and (B) an SC/ISE PPY layer (redox capacitance layer).

The response time for the proposed electrodes was evaluated after successive immersion of the sensors in ascending $\mathrm{Ca}^{2+}$ ion concentrations. Within the concentration range $1.0 \times 10^{-7}$ to $1.0 \times 10^{-2} \mathrm{M}$, the time required to achieve a $95 \%$ of the equilibrium potential was found to be less than $10 \mathrm{~s}$ for all proposed sensors as shown in Figure 1. Relative standard deviations of $2.5 \%$ and $3.1 \%(n=5)$ are calculated for full reversible potential response obtained by both C/PPY/Ca ${ }^{2+}$-ISEs and $\mathrm{C} / \mathrm{GO} / \mathrm{Ca}^{2+}$-ISEs, respectively.

The $\mathrm{pH}$ effect on the potential response of the developed electrodes was examined over the $\mathrm{pH}$ range 2 to 10 for $1.0 \times 10^{-4} \mathrm{M} \mathrm{Ca}^{2+}$ solutions using hydrochloric acid/sodium hydroxide solutions. As shown in Figure 3, all sensors exhibited a stable potential response over the $\mathrm{pH}$ range 3.5 to 8.4. At $\mathrm{pH}>8.5$, the potential begins to decline due to the formation of the detectable $\mathrm{Ca}(\mathrm{OH})_{2}$ species. Below $\mathrm{pH}<3.5$, the potential response is decreased, which can result from the dissociation of the $\mathrm{Ca}(\mathrm{II})$-bilirubinate complex. All subsequent measurements were carried out in $50 \mathrm{mM}$, tris buffer solution of $\mathrm{pH} 5$, which is suitable for the formation of Ca-bilirubinate complex [26]. 


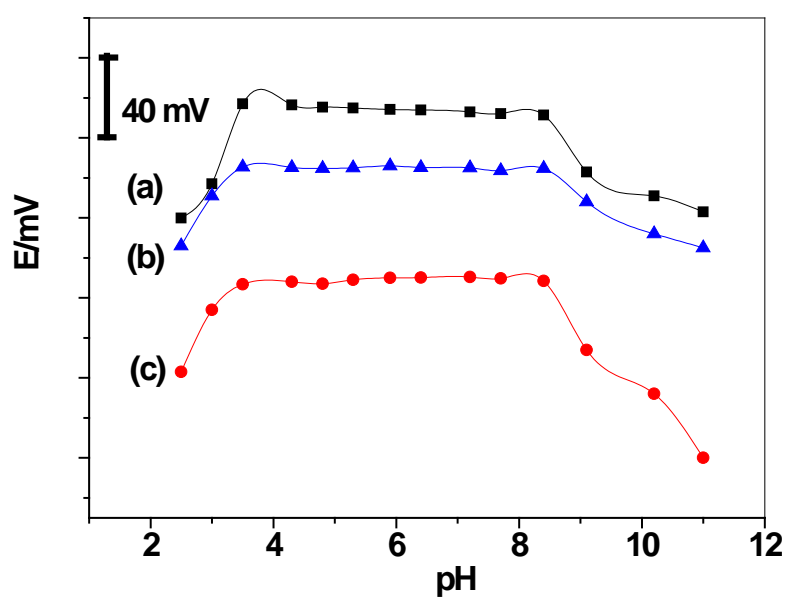

Figure 3. Potential/pH plots for (a) C/GO/Ca ${ }^{2+}$-ISEs; (b) C/PPY/Ca ${ }^{2+}$-ISEs; and (c) C/Ca ${ }^{2+}$-ISEs.

One of the most important performance characteristics in ion-selective electrodes (ISEs) is its selectivity towards the primary ion over other ions. Selectivity of both $\mathrm{C} / \mathrm{PPY} / \mathrm{Ca}^{2+}$-ISEs and $\mathrm{C} / \mathrm{GO} / \mathrm{Ca}^{2+}$-ISEs was examined using the method proposed by Bakker modified (i.e., separate solution method (MSSM)) (by extrapolating the response functions to $a_{j}=1 \mathrm{M}$ ) [28]. All selectivity coefficient values obtained for the $\mathrm{C} / \mathrm{PPY} / \mathrm{Ca}^{2+}$-ISEs and $\mathrm{C} / \mathrm{GO} / \mathrm{Ca}^{2+}$-ISEs were summarized in Table 2. It can be seen that $\mathrm{C} / \mathrm{PPY} / \mathrm{Ca}^{2+}$-ISEs and $\mathrm{C} / \mathrm{GO} / \mathrm{Ca}^{2+}$-ISEs exhibited high $\mathrm{Ca}^{2+}$ selectivity over interfering ions and the selectivity was not affected by the inserted transducer material, but is dependent on the ion-sensing membrane (ISM) itself. This selectivity behavior satisfied the fulfillments required for calcium determination in different matrix samples.

Table 2. Potentiometric selectivity coefficient $\log \mathrm{K}^{\mathrm{pot}} \mathrm{Ca}^{2+}{ }_{J}$ for the proposed calcium-ISEs.

\begin{tabular}{|c|c|c|c|c|c|c|c|}
\hline \multirow{2}{*}{ Sensor Type } & \multicolumn{7}{|c|}{$\log K^{p o t} \mathrm{Ca}^{2+}{ }^{2+}$} \\
\hline & $\mathrm{Na}^{+}$ & $\mathrm{K}^{+}$ & $\mathrm{NH}_{4}{ }^{+}$ & $\mathrm{Mg}^{2+}$ & $\mathrm{Ba}^{2+}$ & $\mathrm{Fe}^{2+}$ & $\mathrm{Li}^{+}$ \\
\hline $\mathrm{C} / \mathrm{PPY} / \mathrm{Ca}^{2+}$-ISEs & $-4.3 \pm 0.3$ & $-3.7 \pm 0.5$ & $-3.9 \pm 0.8$ & $-5.1 \pm 0.3$ & $-5.8 \pm 0.2$ & $-3.9 \pm 0.4$ & $-6.3 \pm 0.2$ \\
\hline $\mathrm{C} / \mathrm{GO} / \mathrm{Ca}^{2+}$-ISEs & $-4.4 \pm 0.2$ & $-3.8 \pm 0.7$ & $-3.8 \pm 0.7$ & $-5.3 \pm 0.1$ & $-5.7 \pm 0.4$ & $-3.5 \pm 0.7$ & $-6.1 \pm 0.5$ \\
\hline $\mathrm{C} / \mathrm{Ca}^{2+}$-ISEs & $-4.2 \pm 0.5$ & $-3.7 \pm 0.4$ & $-3.6 \pm 0.6$ & $-5.4 \pm 0.2$ & $-5.6 \pm 0.3$ & $-3.1 \pm 0.8$ & $-6.2 \pm 0.3$ \\
\hline
\end{tabular}

\subsection{Chronopotentiometry}

Reversed-current chronopotentiometry $( \pm 1 \mathrm{nA})$ was used to determine the short-term potential stability of the $\mathrm{C} / \mathrm{PPY} / \mathrm{Ca}^{2+}$-ISEs and $\mathrm{C} / \mathrm{GO} / \mathrm{Ca}^{2+}$-ISEs. Typical chronopotentiograms for $\mathrm{C} / \mathrm{Ca}^{2+}$-ISEs, $\mathrm{C} / \mathrm{PPY} / \mathrm{Ca}^{2+}$-ISEs and C/GO/Ca ${ }^{2+}$-ISEs were shown in Figure 4. The potential drifts for the presented electrodes were calculated from the slope $(\Delta E / \Delta t)$ of the potential-time plot. They were found to be $112.2,18.3$, and $11.4 \mu \mathrm{V} / \mathrm{s}$ for $\mathrm{C} / \mathrm{Ca}^{2+}$-ISEs, C/PPY/Ca ${ }^{2+}$-ISEs, and C/GO/Ca ${ }^{2+}$-ISEs, respectively. It was noticed that the insertion of a solid-contact layer between the ion-sensing membrane (ISM) and the conducting substrate (carbon) enhanced the potential stability of the electrodes as compared to the electrodes with no solid-contact layer (i.e., $\mathrm{C} / \mathrm{GO} / \mathrm{Ca}^{2+}$-ISEs). In addition, $\mathrm{GO}$ based electrodes revealed higher potential stability than PPY based electrodes. The low-frequency capacitance values for $\mathrm{C} / \mathrm{Ca}^{2+}{ }_{-}$ISEs, $\mathrm{C} / \mathrm{PPY} / \mathrm{Ca}^{2+}$-ISEs, and $\mathrm{C} / \mathrm{GO} / \mathrm{Ca}^{2+}{ }_{-}$ISEs were calculated from the equation $(\Delta E / \Delta t=I / C)$ [29], and found to be $8.9 \pm 0.8,54.6 \pm 1.1$ and $88.4 \pm 1.3 \mu \mathrm{F}$, respectively. The bulk resistance of the membrane sensors $\left(R_{t}=\Delta E / I\right)$ were also calculated and were found to be $R_{t}=1.22,0.36$ and $0.67 \mathrm{M}^{\prime} \Omega$ for $\mathrm{C} / \mathrm{Ca}^{2+}$-ISEs, C/PPY/Ca ${ }^{2+}$-ISEs, and $\mathrm{C} / \mathrm{GO} / \mathrm{Ca}^{2+}{ }^{2+}$ ISEs, respectively. A comparison between the response characteristics of previously reported $\mathrm{Ca}^{2+}$-ISEs with different ion-to-electron transducers and the sensors reported in this study is presented in Table 3. 


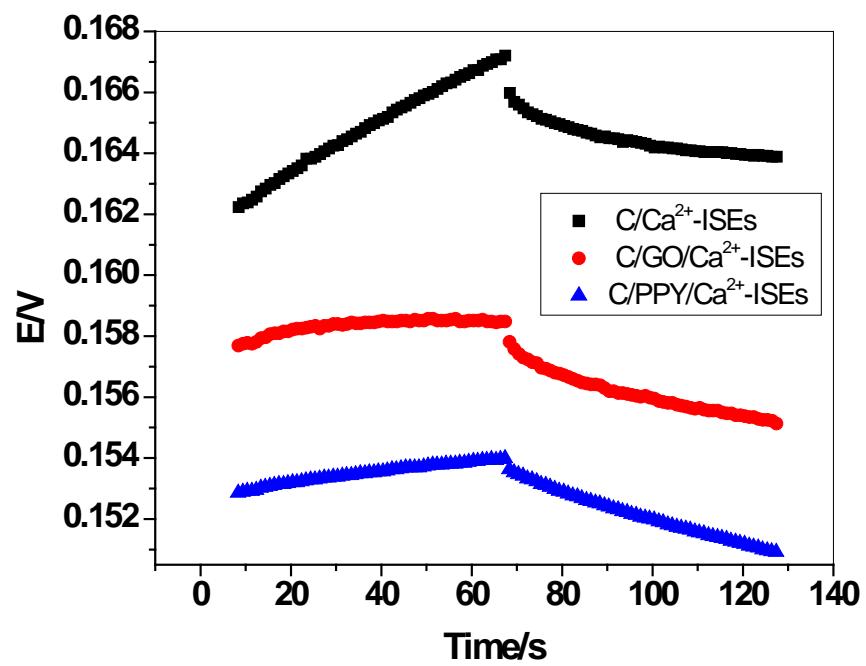

Figure 4. For all solid-state $\mathrm{Ca}^{2+} /$ ISEs.

Table 3. Between various functional materials used as solid-contact transducers in $\mathrm{Ca}^{2+}$-ISEs.

\begin{tabular}{|c|c|c|c|c|c|c|c|}
\hline Ionophore & $\begin{array}{l}\text { Functional } \\
\text { Materials }\end{array}$ & $\begin{array}{l}\text { Conductive } \\
\text { Substrate }\end{array}$ & $\begin{array}{l}\text { Detection } \\
\text { Limit, } \mathbf{M}\end{array}$ & $\begin{array}{c}\text { Slope, } \\
\text { mV/decade }\end{array}$ & $\begin{array}{c}\text { Potential } \\
\text { Drift, } \mu \mathrm{V} / \mathrm{s}\end{array}$ & $\begin{array}{c}\text { Interfacial } \\
\text { Capacitance, } \mu \mathrm{F}\end{array}$ & Ref. \\
\hline $\begin{array}{c}\text { Calcium } \\
\text { ionophore IV } \\
(\text { ETH 5234) }\end{array}$ & Black phosphorus & GC & $4.0 \times 10^{-7}$ & $28.3 \pm 0.7$ & 72 & - & {$[30]$} \\
\hline $\begin{array}{c}\text { Calcium } \\
\text { ionophore II } \\
\text { (ETH129) }\end{array}$ & SWCNTs & $\mathrm{Cu}$ & $6.3 \times 10^{-7}$ & 28.7 & 930 & 5.37 & [31] \\
\hline $\begin{array}{c}\text { Calcium } \\
\text { ionophore II }\end{array}$ & P-NPEDMA & $\mathrm{Au}$ & $3.2 \times 10^{-6}$ & $30.2 \pm 0.5$ & - & - & {$[32]$} \\
\hline $\begin{array}{l}\text { Calcichrome } \\
\text { Calcium }\end{array}$ & Polypyrrole & Pt or GC & $1.0 \times 10^{-5}$ & $29.1 \pm 0.8$ & - & - & [33] \\
\hline $\begin{array}{c}\text { ionophore IV } \\
\text { (ETH 5234) }\end{array}$ & Polyazulene & $\mathrm{Pt} / \mathrm{ZnSe}$ & - & - & 0.14 & 874 & {$[34]$} \\
\hline $\begin{array}{c}\text { Calcium } \\
\text { ionophore IV } \\
\text { (ETH 5234) }\end{array}$ & POT & $\mathrm{Pt} / \mathrm{ZnSe}$ & $2.0 \times 10^{-8}$ & $27.3 \pm 0.1$ & - & - & [35] \\
\hline $\begin{array}{c}\text { Calcium } \\
\text { ionophore I } \\
(\mathrm{ETH}-1001)\end{array}$ & POT & GC & $1.0 \times 10^{-6}$ & $25.0 \pm 0.9$ & - & - & [36] \\
\hline $\begin{array}{c}\text { Calcium } \\
\text { ionophore II } \\
\text { (ETH129) }\end{array}$ & PEDOT/PSS & Carbon & $1.0 \times 10^{-4}$ & $30.0 \pm 1.0$ & - & - & [37] \\
\hline $\begin{array}{c}\text { Calcium } \\
\text { ionophore II } \\
\text { (ETH129) }\end{array}$ & PEDOT/PSS & $\mathrm{Pt}$ & $1.0 \times 10^{-6}$ & 27.7 & - & - & [38] \\
\hline $\begin{array}{c}\text { Calcium } \\
\text { ionophore I } \\
(\mathrm{ETH}-1001)\end{array}$ & Graphene/Polyaniline & GC & $5.0 \times 10^{-8}$ & $28.7 \pm 0.1$ & 87 & 11 & [39] \\
\hline Bilirubin & $\begin{array}{c}\text { Polypyrrol } \\
\text { Graphene oxide }\end{array}$ & Carbon & $\begin{array}{l}3.8 \times 10^{-6} \\
2.3 \times 10^{-7}\end{array}$ & $\begin{array}{l}38.1 \pm 0.4 \\
31.1 \pm 0.6\end{array}$ & $\begin{array}{l}18.3 \\
11.4\end{array}$ & $\begin{array}{l}54.6 \\
88.4\end{array}$ & This work \\
\hline
\end{tabular}

P-NPEDMA: n-phenyl-ethylenediamine-methacrylamide; POT: poly (3-octylthiophene); GC: glassy carbon; PEDOT/PSS: poly (3,4-ethylenedioxythiophene) (PEDOT) doped with poly (styrenesulfonate) (PSS).

\subsection{Electrochemical Impedance Spectroscopy}

For further characterization, to study the quality of both GO and PPY as solid contacts, electrochemical impedance spectroscopy (EIS) was carried out in $10^{-3} \mathrm{MCaCl}_{2}$ with the frequency range of $1 \mathrm{~Hz}-10 \mathrm{kHz}, E_{d c}=0.2 \mathrm{~V}$, and $\Delta E_{d c}=10 \mathrm{mV}$. The impedance spectra for $\mathrm{C} / \mathrm{Ca}^{2+}$-ISEs, $\mathrm{C} / \mathrm{PPY} / \mathrm{Ca}^{2+}{ }_{-}$ISEs and $\mathrm{C} / \mathrm{GO} / \mathrm{Ca}^{2+}$-ISEs are shown in Figure 5. Form the high-frequency semicircle, the bulk membrane between the electronic conductor or solid-contact and the ISM can be evaluated. The resistances were found to be 7.6, 51.2, and 83.5 $\mathrm{M}^{\prime} \Omega$ for $\mathrm{C} / \mathrm{Ca}^{2+}$-ISEs, C/PPY/Ca ${ }^{2+}$-ISEs, and C/GO/Ca ${ }^{2+}$-ISEs, respectively. This confirms that the charge-transfer across the interfaces is facilitated due to the presence of the solid-contact transducer. The low-frequency semicircle is associated with the interfacial capacitance 
(i.e., double-layer capacitance in case of GO and redox capacitance in case of PPY). The calculated interfacial capacitances were found to be $3.07,0.11$ and $0.15 \mu \mathrm{F}$ for $\mathrm{C} / \mathrm{Ca}^{2+}{ }_{-}$ISEs, C/PPY/Ca ${ }^{2+}$-ISEs, and $\mathrm{C} / \mathrm{GO} / \mathrm{Ca}^{2+}$-ISEs, respectively. The results indicate that the presence of either PPY or GO as solid-contact transducers between the ISM and the electronic conductor substrate increased the low-frequency capacitance of the proposed all-solid-state $\mathrm{Ca}^{2+}$-ISE.

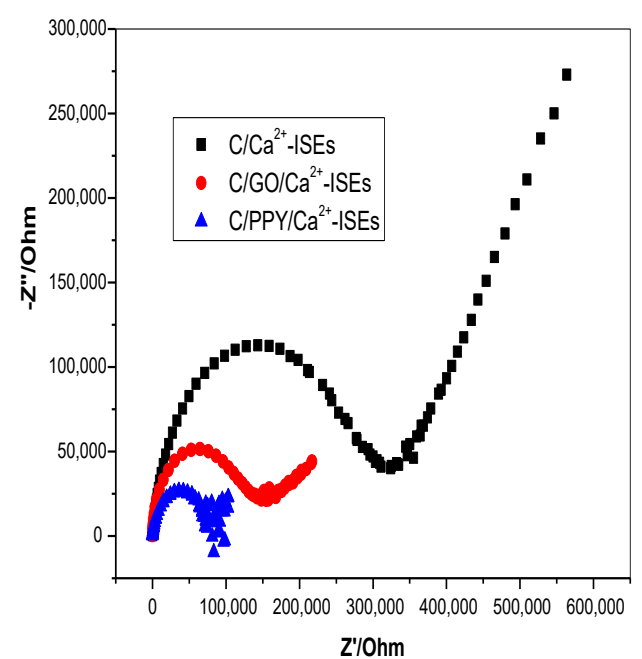

(a)

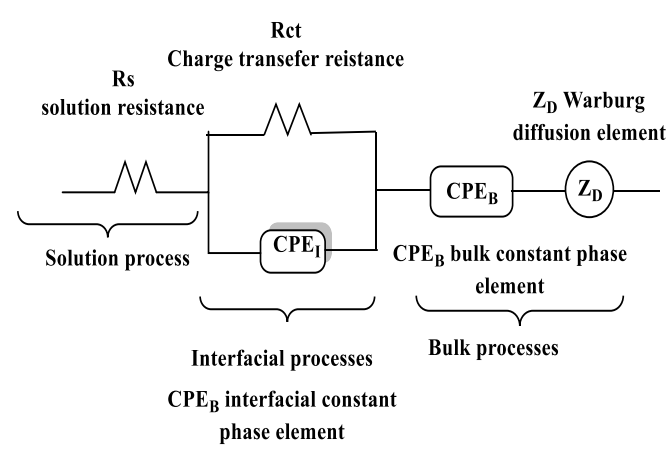

(b)

Figure 5. (a) Impedance spectra for all solid-state $\mathrm{Ca}^{2+} / \mathrm{ISEs}$; (b) equivalent circuit for the proposed electrodes.

\subsection{Water-Layer Test}

To test the formation of water layer between the ion-sensing membrane and the internal electrode, the electrodes were initially inserted in $10^{-2} \mathrm{M} \mathrm{CaCl}_{2}$ solution. After $12 \mathrm{~h}$, the solution was changed to the discriminating ion solution $(0.1 \mathrm{M} \mathrm{NaCl})$. After $4 \mathrm{~h}$, the discriminating ion solution was replaced by $10^{-2} \mathrm{M} \mathrm{CaCl}_{2}$ solution. The potential readings vs. time were plotted and presented in Figure 6 . Both C/PPY $/ \mathrm{Ca}^{2+}$-ISEs and $\mathrm{C} / \mathrm{GO} / \mathrm{Ca}^{2+}$-ISEs showed very stable potentials upon replacing the primary ions by the discriminated ions while $\mathrm{C} / \mathrm{Ca}^{2+}$-ISEs exhibited a significant potential drift. This can confirm that, when the hydrophobic solid-contact materials are inserted between the ion-sensing membrane and electronic conductor, no aqueous layer will be formed, and a stable electrode potential will be obtained.

\subsection{Analytical Applications}

To verify the successful application of the proposed sensors, these electrodes were used for calcium ion determination in different matrices such as some baby-food products, pharmaceutical formulations, and human serum samples. As shown in Table 4, the data obtained using the proposed sensors are in good agreement with those obtained from AAS measurements [40] for both baby-food and pharmaceutical formulation samples. An $F$-test showed no observable difference between means and variances of the sets of results obtained by the two methods at $95 \%$ confidence level. The $F$-values calculated $(n=6)$ were found to be in the range of 2.51-5.15 compared with the tabulated value (6.39) at the $95 \%$ confidence level. 


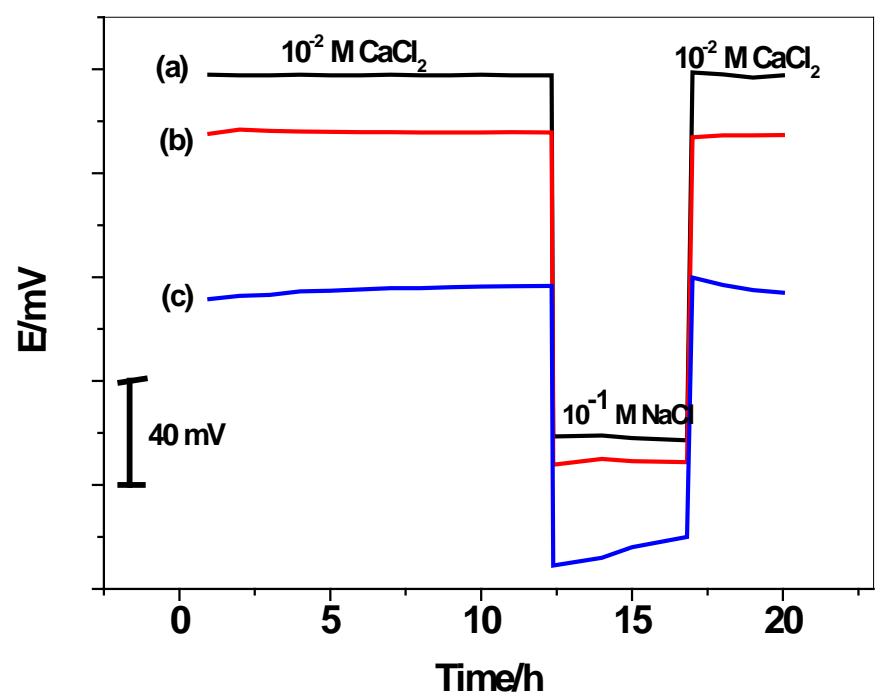

Figure 6. Water-layer test for (a) C/GO/Ca ${ }^{2+}$-ISEs; (b) C/PPY/Ca ${ }^{2+}$-ISEs; and (c) C/Ca ${ }^{2+}$-ISEs.

Table 4. Assessment of Calcium content in some baby-food products and pharmaceutical formulations.

\begin{tabular}{|c|c|c|c|c|c|c|}
\hline \multirow{2}{*}{ Sample } & \multirow{2}{*}{$\begin{array}{l}\text { Labeled Amount } \\
\mathrm{mg} / \mathrm{tab} \text {. or mg/g }\end{array}$} & \multicolumn{2}{|c|}{ Potentiometry } & \multicolumn{2}{|c|}{ AAS } & \multirow{2}{*}{${ }^{b} F$-Test } \\
\hline & & mg/tab. or Cap. & ${ }^{a}$ Mean $\% \pm$ SD & mg/tab. or Cap. & ${ }^{a}$ Mean $\% \pm$ SD & \\
\hline \multicolumn{7}{|l|}{$\begin{array}{l}\text { Pharmaceutical } \\
\text { formulations }\end{array}$} \\
\hline $\begin{array}{c}\text { Calcimate } \\
\text { (ADWIC, Egypt) }\end{array}$ & $500 \mathrm{mg} / \mathrm{tablet}$ & $497.3 \pm 1.2$ & $99.4 \pm 0.7$ & $499.2 \pm 0.2$ & $99.8 \pm 0.1$ & 4.46 \\
\hline $\begin{array}{l}\text { Vitacid calcium } \\
\text { (CID, Egypt) }\end{array}$ & $800 \mathrm{mg} /$ tablet & $787.3 \pm 3.1$ & $98.4 \pm 1.1$ & $795.1 \pm 0.7$ & $99.4 \pm 0.2$ & 3.72 \\
\hline \multicolumn{7}{|l|}{$\begin{array}{l}\text { Baby-food } \\
\text { products }\end{array}$} \\
\hline Cerelac + rice & $4.3 \mathrm{mg} / \mathrm{g}$ & $3.9 \pm 0.3$ & $90.7 \pm 1.2$ & $4.1 \pm 0.5$ & $95.3 \pm 2.1$ & 1.76 \\
\hline $\begin{array}{l}\text { Cerelac }+ \text { wheat } \\
+4 \text { fruits } \\
\text { Nestle }^{\circledR} \text { NIDO }^{\circledR}\end{array}$ & $5.0 \mathrm{mg} / \mathrm{g}$ & $4.7 \pm 0.6$ & $94 \pm 2.2$ & $5.04 \pm 0.4$ & $100.8 \pm 0.4$ & 2.23 \\
\hline $\begin{array}{l}\text { FORTIFIED } \\
\text { Milk Powder Tin } \\
900 \mathrm{~g}\end{array}$ & $8.6 \mathrm{mg} / \mathrm{g}$ & $8.8 \pm 0.4$ & $102.3 \pm 0.4$ & $8.7 \pm 0.2$ & $101.1 \pm 0.7$ & 3.34 \\
\hline
\end{tabular}

${ }^{\mathrm{a}}$ Mean of three replicate measurements \pm standard deviation (SD); ${ }^{\mathrm{b}}$ F-test at $95 \%$ confidence level values is 6.39 .

The sensors were successfully applied for calcium ion determination in human blood as a biological fluid, where blood samples were collected from different volunteers and the results are listed in Table 5 . F-test showed no observable difference between means and variances of the two sets of results obtained by the methods at the $95 \%$ confidence level. The $F$-values calculated $(n=6)$ were found to be in the range of 1.76-4.46, compared with the tabulated value (6.39) at the $95 \%$ confidence level.

Table 5. Of calcium in human serum samples using the proposed electrodes and the AAS reference method.

\begin{tabular}{cccc}
\hline \multirow{2}{*}{ Sample } & \multicolumn{2}{c}{${ }^{*}$ Calcium Content, $\mathbf{~ m g / d L}$} & \multirow{2}{*}{ a F-Test } \\
\cline { 2 - 3 } & Potentiometry & AAS & \\
\hline Volunteer 1 & $9.3 \pm 1.5$ & $9.5 \pm 0.7$ & 4.12 \\
Volunteer 2 & $10.5 \pm 0.9$ & $10.3 \pm 0.3$ & 3.36 \\
Volunteer 3 & $7.8 \pm 0.6$ & $8.4 \pm 0.2$ & 1.43 \\
\hline
\end{tabular}

* Mean of three replicate measurements \pm standard deviation (SD); ${ }^{\text {a }}$-test at $95 \%$ confidence level values is 6.39 . 


\section{Conclusions}

A new type of solid-contact calcium sensors was fabricated characterized and presented for calcium ion determination. Polypyrrol (PPY) and graphene oxide (GO) have been used as ion-to-electron transducers in screen printed solid-contact $\mathrm{Ca}^{2+}$-ISEs. The presence of such layers significantly reduced the membrane resistance and enhanced the short-term potential stability of the presented electrodes. In a $50 \mathrm{mM}$ tris buffer solution of $\mathrm{pH} 5$, the sensors revealed good analytical parameters: near-Nernstian responses for $\mathrm{Ca}^{2+}$ ions with slopes of $38.1 \pm 0.4\left(\mathrm{r}^{2}=0.996\right)$ and $31.1 \pm 0.6\left(\mathrm{r}^{2}=0.999\right) \mathrm{mV} / \mathrm{decade}$, detection limits of $3.8 \times 10^{-6}(0.152 \mu \mathrm{g} / \mathrm{mL})$ and $2.3 \times 10^{-7} \mathrm{M}(8.0 \mathrm{ng} / \mathrm{mL})$, and linear concentration ranges of $7.0 \times 10^{-6}-1.0 \times 10^{-2}(400-0.28 \mu \mathrm{g} / \mathrm{mL})$ and $7.0 \times 10^{-7}-1.0 \times 10^{-2} \mathrm{M}(400-0.028 \mu \mathrm{g} / \mathrm{mL})$ for sensors based on PPY and GO, respectively. These reliable and robust sensors were successfully applied for calcium ion determination in different baby-food products, pharmaceutical formulations, and human blood samples. The results obtained compared favorably with data collected using atomic absorption spectrometry (AAS).

Author Contributions: The listed authors contributed to this work as described in the following: H.S.M.A.-R. and A.H.K. provided the concepts of the work, interpretation of the results, the experimental part and prepared the manuscript; A.H.K., H.S.M.A.-R., and A.E.-G.E.A. cooperated in the preparation of the manuscript; A.H.K. and H.S.M.A.-R. performed the revision before submission; A.E.-G.E.A. secured the financial support for the work. All authors have read and agreed to the published version of the manuscript.

Funding: This research was funded by the Vice Deanship of Scientific Research Chairs.

Acknowledgments: The authors are grateful to the Deanship of Scientific Research, king Saud University for funding through Vice Deanship of Scientific Research Chairs.

Conflicts of Interest: The authors declare no conflict of interest.

Ethical Statement : All subjects gave their informed consent for inclusion before they participated in the study. The study was conducted in accordance with the Declaration of Helsinki, and the protocol was approved by the Ethics Committee of National Research Centre for Medical Research (HU/IACUC20187).

\section{References}

1. Grishin, S.N. Transmembrane calcium current: Mechanism, registration procedures, calcium-mediated modulators of synaptic transmission. Biochem. (Moscow) Suppl. Ser. Membr. Cell Biol. 2014, 8, $213-224$. [CrossRef]

2. Byrnes, M.C.; Huynh, K.; Helmer, S.D.; Stevens, C.; Dort, J.M.; Smith, R.S. A comparison of corrected serum calcium levels to ionized calcium levels among critically ill surgical patients. Am. J. Surg. 2005, 189, 310-314. [CrossRef]

3. Kochegarov, A.A. Pharmacological modulators of voltage-gated calcium channels and their therapeutical application. Cell Calcium 2003, 33, 145-162. [CrossRef]

4. Robertson, W.G. Measurement of Ionised Calcium in Body Fluids-A Review. Annals Clin. Biochem. Int. Lab. Med. 1976, 13, 540-548. [CrossRef]

5. Ross, J.W. Calcium-selective electrode with liquid ion exchanger. Science 1967, 156, 1378-1379. [CrossRef]

6. Young, C.C. Evolution of blood chemistry analyzers based on ion selective electrodes. J. Chem. Educ. 1997, 74, 177-182. [CrossRef]

7. Haugland, R.P.; Johnson, I.D. Intracellular ion indicators. In Fluorescent and Luminescent Probes for Biological Activity; Mason, W.T., Ed.; Academic Press: London, UK, 1999; pp. 40-50.

8. Dimeski, G.; Badrick, T.; John, A.S. Ion selective electrodes (ISEs) and interferences-A review. Clin. Chim. Acta 2010, 411, 309-317. [CrossRef] [PubMed]

9. Ashmawy, N.H.; Almehizia, A.A.; Youssef, T.A.; El-Galil, E.A.A.; Al-Omar, M.A.; Kamel, A.H. Novel Carbon/PEDOT/PSS-Based screen-printed biosensors for acetylcholine neurotransmitter and acetylcholinesterase detection in human serum. Molecules 2019, 24, 1539. [CrossRef] [PubMed]

10. Hassan, S.S.M.; Elnemma, E.M.; Mohamed, A.H.K. Novel biomedical sensors for flow injection potentiometric determination of creatinine in human serum. Electroanalysis 2005, 17, 2246-2253. [CrossRef]

11. Kamel, A.H.; Hassan, A.M.E. Solid contact potentiometric sensors based on host-tailored molecularly imprinted polymers for creatine assessment. Int. J. Electrochem. Sci. 2016, 11, 8938-8949. [CrossRef] 
12. Abdalla, N.S.; Amr, A.E.G.E.; El-Tantawy, A.S.M.; Al-Omar, M.A.; Kamel, A.H.; Khalifa, N.M. Tailor-madespecific recognition of cyromazine pesticide integrated in a potentiometric strip cell for environmental andfood analysis. Polymers 2019, 11, 1526. [CrossRef] [PubMed]

13. GalalEldin, A.; Amr, E.; El-Galil, A.; Kamel, A.H.; Hassan, S.S.M. Screen-printed Microsensors UsingPolyoctyl-thiophene (POT) conducting polymer as solid transducer for ultratrace determination of Azides. Molecules 2019, 24, 1392. [CrossRef] [PubMed]

14. Van de Velde, L.; d'Angremont, E.; Olthuis, W. Solid contact potassium selective electrodes for biomedical applications-A review. Talanta 2016, 160, 56-65. [CrossRef] [PubMed]

15. Lindfors, T.; Ivaska, A. All-solid-state calcium-selective electrode prepared of soluble electrically conducting polyaniline and di(2-ethylhexyl)phosphate with tetraoctylammonium chloride as cationic additive. Anal. Chim. Acta 2000, 404, 111-119. [CrossRef]

16. Sundfors, F.; Bereczki, R.; Bobacka, J.; Toth, K.; Ivaska, A.; Gyurcsanyi, R.E. Microcavity based solid-contact ion-selective microelectrodes. Electroanalysis 2006, 18, 1372-1378. [CrossRef]

17. Zachara, J.E.; Toczylowska, R.; Pokrop, R.; Zagórska, M.; Dybko, A.; Wróblewski, W. Miniaturized all-solid-state potentiometric ion sensors based on PVC-membranes containing conducting polymers. Sens. Actuators B 2004, 101, 207-212. [CrossRef]

18. Zine, N.; Bausells, J.; Teixidor, F.; Vinas, C.; Masalles, C.; Samitier, J.; Errachid, A. All solid-state hydrogen sensing microelectrodes based on novel PPy[3,3'-Co(1,2-C2B9H11)2] as a solid internal contact. Mater. Sci. Eng. C 2006, 26, 399-404. [CrossRef]

19. Pandey, P.C.; Prakash, R. Polyindole modified potassium ion-sensor using dibenzo-18-crown-6 mediated PVC matrix membrane. Sens. Actuators B 1998, 46, 61-65. [CrossRef]

20. Zine, N.; Bausells, J.; Vocanson, F.; Lamartine, R.; Asfari, Z.; Teixidor, F.; Crespo, E.; de Oliveira, I.A.M.; Samitier, J.; Errachid, A. Potassium-ion selective solid contact microelectrode based on a novel 1,3-(di-4-oxabutanol)-calix[4]arene-crown-5 neutral carrier. Electrochim. Acta 2006, 51, 5075-5079. [CrossRef]

21. Correia, D.P.A.; Magalhaes, J.M.C.S.; Machado, A.A.S.C. Array of potentiometric sensors for simultaneous analysis of urea and potassium. Talanta 2005, 67, 773-782. [CrossRef]

22. Lindfors, T.; Ivaska, A. All-solid-state calcium-selective electrode prepared of soluble electrically conducting polyaniline and di(2-ethylhexyl)phosphate with ETH1001 as neutral carrier. Anal. Chim. Acta 2000, 404, 101-110. [CrossRef]

23. Tymecki, L.; Glab, S.; Koncki, R. Miniaturized, planar ion-selective electrodes fabricated by means of thick-film technology. Sensors 2006, 6, 390-396. [CrossRef]

24. Singh, A.K.; Mehtab, S. Calcium(II)-selective potentiometric sensor based on $\alpha$-furildioxime as neutral carrier. Sens. Actuators B 2007, 123, 429-436. [CrossRef]

25. Wang, S.H.; Chou, T.C.; Liu, C.C. Development of a solid-state thick film calcium ion-selective electrode. Sens. Actuators B 2003, 96, 709-716. [CrossRef]

26. Sutor, D.J.; Wilkie, L.I. The crystalline salts of calcium bilirubinate in human gallstones. Clin. Sci. Mol. Med. 1977, 53, 101-103. [CrossRef] [PubMed]

27. Black, B.E.; Carr, S.H.; Ostrow, J.D. Equilibrium swelling of pigment gallstones: Evidence for network polymer structure. Biopolymers 1982, 21, 601-610. [CrossRef]

28. Bakker, E.; Pretsch, E.; Bühlman, P. Selectivity of potentiometric ion sensors. Anal. Chem. 2000, 72, 1127-1133. [CrossRef]

29. Bobacka, J. Potential stability of all-solid-state ion-selective electrodes using conducting polymers as ion-to-electron transducers. Anal. Chem. 1999, 71, 4932-4937. [CrossRef]

30. Kou, L.; Fu, M.; Liang, R. Solid-contact $\mathrm{Ca}^{2+}$-selective electrodes based on two-dimensional black phosphorus as ion-to-electron transducers. RSC Adv. 2017, 7, 43905-43908. [CrossRef]

31. Hernandez, R.; Riu, J.; Rius, F.X. Determination of calcium ion in sap using carbon nanotube-based ion-selective electrodes. Analyst 2010, 135, 1979-1985. [CrossRef]

32. Abramova, N.; Moral-Vico, J.; Soley, J.; Ocaña, C.; Bratov, A. Solid contact ion sensor with conducting polymer layer copolymerized with the ion-selective membrane for determination of calcium in blood serum. Anal. Chim. Acta 2016, 943, 50-57. [CrossRef] [PubMed]

33. Blaz, T.; Migdalski, J.; Lewenstam, A. Polypyrrole-calcion film as a membrane and solid-contact in an indicator electrode for potentiometric titrations. Talanta 2000, 52, 319-328. [CrossRef] 
34. He, N.; Hofler, L.; Latonen, R.; Lindfors, T. Influence of hydrophobization of the polyazulene ion-to-electron transducer on the potential stability of calcium-selective solid-contact electrodes. Sens. Actuators B 2015, 207, 918-925. [CrossRef]

35. Lindfors, T.; Sundfors, F.; Hofler, L.; Gyurcsanyi, R.E. The water uptake of plasticized Poly(vinyl chloride) solid-contact calcium-selective electrodes. Electroanalysis 2011, 23, 2156-2163. [CrossRef]

36. Michalska, A.; Konopka, A.; Maj-Zurawska, M. All-solid-state calcium solvent polymeric membrane electrode for low-level concentration measurements. Anal. Chem. 2003, 75, 141-144. [CrossRef]

37. Wang, Y.; Xu, H.; Yang, X.; Luo, Z.; Zhang, J.; Li, G. All-solid-state blood calcium sensors based on screen-printed poly(3,4-ethylenedioxythiophene) as the solid contact. Sens. Actuators B 2012, 173, 630-635. [CrossRef]

38. Xu, H.; Wang, Y.; Luo, Z.; Pan, Y. A miniature all-solid-state calciumelectrode applied to in situ seawater measurement. Meas. Sci. Technol. 2013, 24, 5105. [CrossRef]

39. Boeva, Z.A.; Lindfors, T. Few-layer graphene and polyaniline composite as ion-to-electron transducer in silicone rubber solid-contact ion-selective electrodes. Sens. Actuators B 2016, 224, 624-631. [CrossRef]

40. Trudeau, D.L.; Freier, E.F. Determination of calcium in urine and serum by atomic absorption spectrophotometry (AAS). Clin. Chem. 1967, 13, 101-114. [CrossRef]

(C) 2020 by the authors. Licensee MDPI, Basel, Switzerland. This article is an open access article distributed under the terms and conditions of the Creative Commons Attribution (CC BY) license (http://creativecommons.org/licenses/by/4.0/). 